\title{
Aflatoxins Importance on Animal Nutrition
}

\author{
Vivian Feddern, Giniani C. Dors, Fernando de C. Tavernari, \\ Helenice Mazzuco, Anildo Cunha Jr., \\ Everton L. Krabbe and Gerson N. Scheuermann \\ Additional information is available at the end of the chapter
}

http://dx.doi.org/10.5772/51952

\section{Introduction}

Mycotoxins are secondary metabolites produced by several fungal species, toxic to humans, animals and plants. Their ingestion, inhalation or dermal absorption may cause different diseases and even death. These compounds have been described for many decades, however in the beginning of the 1960s, they have been chemically characterized due to the discovery of aflatoxins [1]. The word aflatoxin is the combination of 3 other words "a" for Aspergillus genus, "fla" for the species flavus and toxin, meaning poison [2].

Aflatoxin is the mycotoxin generating the greatest losses and the highest management costs due to its extremely high toxicity on a unit basis, and its long history of stringent regulation. The costs are inversely related to the regulatory level that must be met, and lower concentration allowances will increase the costs of crop management. Several effective ways for the management of mycotoxin contamination in agriculture have been stressed. One strategy to manage mycotoxin contamination and decrease health risks and economic costs is to instruct food producers and handlers on how to minimize mycotoxin contamination, and to encourage the adoption of process-based guidelines such as Good Agricultural Practices (GAPs) before harvest and good manufacturing practices (GMPs) after harvest. These actions would minimize risk throughout the production, handling, and processing chain, and can complement product standards [3]. To control the presence of aflatoxins in foods, many countries established maximum tolerated concentrations through legislation (Van Egmond, 1989a cited [4]).

This chapter focuses on properties of aflatoxins and their occurrence in feeds and animal products as meat, eggs, liver, kidneys and milk. Topics regarding mycotoxins absorbents and legislation in feed ingredients and feeds are also covered. 


\section{Aflatoxin properties}

All mycotoxins are low-molecular-weight natural products (i.e., small molecules) (Bennett, 1987 cited [3]). The hyphal structure of filamentous fungi has evolved to utilize solid substrates efficiently by growing over surfaces and penetrating into solid matrices. Moulds are able to secrete enzymes to break down complex macromolecular compounds and utilize them for growth and metabolism. They can absorb low molecular weight nutrients, produce and secrete secondary metabolites, which are also relatively low molecular weight compounds but not associated with the process of growth and primary metabolism (Bushell, 1989 cited by [4]).

Some aflatoxin derivatives are products of animal metabolism following ingestion of the mould metabolites, which are divided into the B and G groups based on their blue or green fluorescence under UV light when absorbed to solid substrates. A. parasiticus is the most toxigenic species, the majority of strains producing both B and G toxins (Van Egmond, 1989a cited by [4]).

Aflatoxins are crystalline substances, freely soluble in moderately polar solvents such as chloroform, methanol, dimethyl sulfoxide; they dissolve in water to the extent of $10-20 \mathrm{mg} \mathrm{L}^{-1}$. Some important physical and chemical properties of aflatoxins are given in Table 1 [5].

\begin{tabular}{cccccc}
\hline & & & \multicolumn{3}{c}{$\begin{array}{c}\text { UV absorption max } \\
\left(\varepsilon\left(\mathbf{~ m o l}^{-1} \mathbf{~ c m}^{-1}\right)\right) \text {, methanol }\end{array}$} \\
\hline Aflatoxin & Molecular formula & Molecular weight & $\begin{array}{c}\text { Melting } \\
\text { Point }\end{array}$ & $\mathbf{2 6 5 ~ n m}$ & $360-362 ~ \mathbf{~ m}$ \\
\hline $\mathrm{B}_{1}$ & $\mathrm{C}_{17} \mathrm{H}_{12} \mathrm{O}_{6}$ & 312 & $268-269$ & 12,400 & 21,800 \\
\hline $\mathrm{B}_{2}$ & $\mathrm{C}_{17} \mathrm{H}_{14} \mathrm{O}_{6}$ & 314 & $286-289$ & 12,100 & 24,000 \\
\hline $\mathrm{G}_{1}$ & $\mathrm{C}_{17} \mathrm{H}_{12} \mathrm{O}_{7}$ & 328 & $244-246$ & 9,600 & 17,700 \\
\hline $\mathrm{G}_{2}$ & $\mathrm{C}_{17} \mathrm{H}_{14} \mathrm{O}_{7}$ & 330 & $237-240$ & 8,200 & 17,100 \\
\hline
\end{tabular}

Table 1. Physical and chemical properties of aflatoxins.

Due to the important structural diversity (Figure 1) of mycotoxins and the variations in their metabolism, it is difficult to edit general rules. Thus, each toxin and respective metabolites have to be investigated as a particular case. The chemical and physical properties of aflatoxins are described as follows [6]:

i. Description: Colorless to pale-yellow crystals. Intensely fluorescent in ultraviolet light, emitting blue (aflatoxins $B_{1}$ and $B_{2}$ ) or green (aflatoxin $G_{1}$ ) and green-blue (aflatoxin $\mathrm{G}_{2}$ ) fluorescence, from which the designations $B$ and $G$ were derived, or blue-violet fluorescence (aflatoxin $\mathrm{M}_{1}$ )

ii. Melting-points: see Table 1.

iii. Absorptionspectroscopy: see Table 1. 
iv. Solubility: Very slightly soluble in water $\left(10-30 \mu \mathrm{g} \mathrm{mL}^{-1}\right)$; insoluble in non-polar solvents; freely soluble in moderately polar organic solvents (e.g., chloroform and methanol) and especially in dimethyl sulfoxide

v. Stability: Unstable to ultraviolet light in the presence of oxygen, to $\mathrm{pH}$ extremes (< $3,>10)$ and to oxidizing agents

vi. Reactivity: The lactone ring is susceptible to alkaline hydrolysis. Aflatoxins are also degraded by reaction with ammonia or sodium hypochlorite.

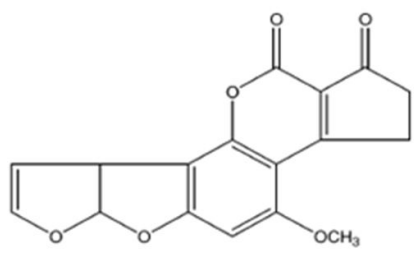

B1

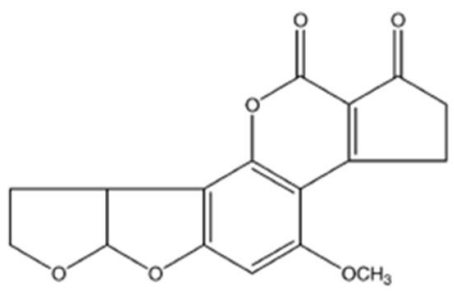

B2

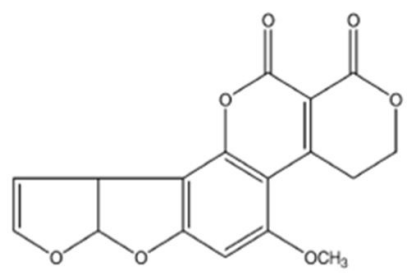

G1

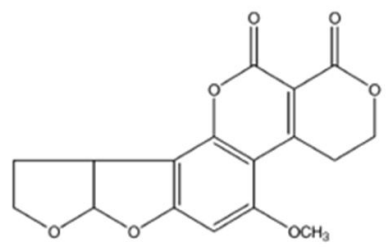

G2

Figure 1. Chemical structures of aflatoxins [7].

Aflatoxins are quite stable in many foods and are fairly resistant to degradation. The effectiveness of some processes in reducing concentrations of aflatoxins in food can be affected by many factors, such as the presence of protein, $\mathrm{pH}$, temperature and length of treatment. Commercial processing of raw commodities using cleaning regimes including the removal of broken particles, milling and sorting can reduce aflatoxin concentration considerably [5].

Naturally occurring aflatoxins (as a group) and other 107 agents were evaluated as carcinogenic to humans (Group 1). There is sufficient evidence in humans for the carcinogenicity of aflatoxins, being liver cancer (hepatocellular carcinoma) the main effect. Aflatoxin $\mathrm{M}_{1}$, the metabolite of aflatoxin $B_{1}$ found in milk of lactating mammals was classified in Group $2 B$ as possibly carcinogenic to humans [8]. Carcinogenicity of naturally occurring mixtures of aflatoxins $B_{1}, G_{1}$ and $M_{1}$ is also demonstrated in experimental animals. The intake of these toxins over a long period of time in very low concentrations may be highly dangerous. These com- 
pounds can enter the food chain, mainly, by ingestion through the diet of humans and animals (Miraglia et al., 1996 cited by [11]).

There is strong evidence that the carcinogenicity of aflatoxins operates by a genotoxic mechanism of action that involves metabolic activation to a genotoxic epoxide metabolite, formation of DNA adducts, and modification of the TP53 gene. In humans, hepatocellular carcinomas from areas of high exposure to aflatoxins, up to $50 \%$ of tumors have been shown to harbor a specific point mutation in the TP53 tumor suppressor gene [9]. Table 2 shows aflatoxin main producing species and toxic effects, pointed by the International Agency for Research on Cancer (IARC).

\begin{tabular}{|c|c|c|c|}
\hline Aflatoxins & Main producing species & CAS No. & Toxic effect \\
\hline $\mathrm{B}_{1}$ & $\begin{array}{c}\text { A. flavus, A. parasiticus, A. nomius, } \\
\text { A. bombycis }\end{array}$ & $1162-65-8$ & $\begin{array}{l}\text { Hepatotoxic, genotoxic, carcinogenic, } \\
\text { immunomodulation }\end{array}$ \\
\hline $\mathrm{B}_{2}$ & $\begin{array}{l}\text { A. flavus, A. parasiticus, A. nomius, } \\
\text { A. bombycis }\end{array}$ & $7220-81-7$ & Limited evidence for carcinogenicity \\
\hline $\mathrm{G}_{1}$ & $\begin{array}{c}\text { A. parasiticus, } A . \text { nomius, } A \text {. } \\
\text { bombycis }\end{array}$ & $1165-39-5$ & Sufficient evidence of carcinogenicity \\
\hline $\mathrm{G}_{2}$ & $\begin{array}{c}\text { A. parasiticus, } A \text {. nomius, } A \text {. } \\
\text { bombycis }\end{array}$ & $7241-98-7$ & Inadequate evidence for carcinogenicity \\
\hline
\end{tabular}

Table 2. Main producing species and effects of aflatoxins $[6,10]$.

$\mathrm{AFB}_{1}$ is the most potent carcinogenic substance naturally produced by Aspergillus species. Indeed, $\mathrm{AFB}_{1}$ is classified by IARC as Group 1 carcinogen [10]. This compound is certainly acutely toxic to humans, is probably responsible for liver necrosis following chronic exposure, and may be involved in the epidemiology of human liver cancer in some parts of the world perhaps synergistically with hepatitis B virus (Van Egmond, 1989a cited by [4]).

After ingestion, aflatoxin B is metabolized by enzymes to generate a reactive 8,9-epoxide metabolite that can be bound to DNA as well as to serum albumin forming aflatoxin-N-7 guanine and lysine adducts, respectively. Covalent binding to DNA is considered to be a critical step in aflatoxin hepatocarcinogenesis [11].

Determination of these metabolites was solved by developing enzyme linked immunosorbent assay (ELISA) methods (Vidyasagar et al., 1997 and Nayak, et al., 2001 cited by [11]). The biosynthesis of aflatoxins is induced by sugars. The induction is associated with the transcriptional activation of the pathway genes and the pathway regulatory gene, aflR. The regulation of aflatoxin biosynthesis had been examined by manipulating the transcription of aflR. Studies concerning this topic showed that constitutive overexpression of the pathway transcriptional regulatory gene aflR led to higher transcript accumulation of pathway genes and increased aflatoxin production (Flaherty and Payne, 1997 cited by [11]). 
Aflatoxins are metabolized in ruminants by the liver and are excreted in the bile. $\mathrm{AFB}_{1}$ increases the apparent protein requirement of cattle. When significant quantities are consumed, the metabolite $M_{1}$ appears in milk within 12 hours. Research suggests $M_{1}$ is not as carcinogenic or mutagenic as $B_{1}$, but it does appear to be as toxic as its parent compound [12]. When an animal ingests food contaminated with an $\mathrm{AFB}_{1}$, from 0.5 to $5 \%$ of the toxin ingested is biotransformed in the liver into $\mathrm{AFM}_{1}$ (Hussein and Brasel, 2001 cited by [13].

On a worldwide basis about $35 \%$ of $A$. flavus strains produce aflatoxins and only the B group. These molds occur in warmer parts of the world and aflatoxins may be produced in a wide range of tropical and subtropical food commodities (Van Egmond, 1989a cited by [4]). The presence of fungi does not necessarily imply the presence of toxins. The fungi species can produce aflatoxins on commodities in the field under stress conditions or in storage when high moisture and warm temperature propitiate their growth (Schuster et al. 1993 cited by [11]). The minimum moisture content of foods that allows the growth of A. flavus is around $85 \%$ relative humidity ( 0.85 water activity), and temperature of $25-30{ }^{\circ} \mathrm{C}$. In cereals with high starch conten as rice, maize, sorghum, wheat, barley, the moisture content in the grain is $18-18.5 \%$. The subsequent drying does not affect the existing level of aflatoxin because it resists drying and roasting temperatures (Pitted, 1998; Sabino, 1996; Wilson and Payne, 1994 cited by [14]). Because of the weather, aflatoxins are commonly found in South America, Africa, Asia and Australia [15].

\section{Aflatoxins occurrence in feeds}

Time of harvest has been shown to be important in influencing the occurrence and levels of aflatoxin because Aspergillus does not compete well with other molds when corn presents more than $20 \%$ moisture. Harvesting corn when moisture content is above $20 \%$ followed by rapid drying to at least $14 \%$ moisture content within 24 to 48 hours of harvest can inhibit Aspergillus growth and toxin production. Contaminated grains and their byproducts are the most common sources of aflatoxin. Corn silage may also be a source of aflatoxins, because the ensiling process does not destroy toxins already present in silage [12].

On the farm, more than one mold or toxin may be present in the contaminated feed, which often makes definitive diagnosis of aflatoxicosis difficult. The prognosis of aflatoxicosis depends upon the severity of liver damage. Once overt symptoms are noticed the prognosis is poor. Treatment should be directed at the severely affected animals in the herd and further poisoning prevented. Aflatoxicosis is typically a herd rather than an individual cow problem. If aflatoxicosis is suspected, feed should be analyzed immediately. If aflatoxins are present, the source should be eliminated immediately. Levels of protein in feed and vitamins A, D, E, K and $B$ should be increased as the toxin binds vitamins and affects protein synthesis. Good management practices to alleviate stress are essential to reduce the risk of secondary infections which must receive immediate attention and treatment [12].

Importantly, it has been demonstrated that simple measures can significantly reduce the risk of mycotoxin exposure on farm. Storage of grain at appropriate moisture content (below $130 \mathrm{~g}$ 
$\mathrm{kg}^{-1}$ ), inspection of grain regularly for temperature, insects and wet spots will limit the possibility of fungal development in feeds and feedstuffs as discussed before. The risk of feed contamination will be reduced in animal units with rapid turnover of feed because there will be less time for fungal growth and toxin production [17]. Aflatoxin is just one of many mycotoxins that can adversely affect animal health and productivity. Care regarding animal feed must be extended not only to the nutritional and economic value, but also to food quality [13].

Decades of animal studies have demonstrated that chronic exposure to aflatoxins in animals can also cause growth inhibition and immune suppression [18]. Nursing animals may be affected, and $\mathrm{AFM}_{1}$ may be excreted in the milk of dairy cattle and other dairy animals. This in turn poses potential health risks to both animals and humans that consume that milk. Chronic aflatoxin exposure in animals can result in impaired reproductive efficiency, reduced feed conversion efficiency, increased mortality rates, reduced weight gain, anemia, and jaundice. In the case of laying hens, aflatoxicosis causes an enlarged fatty liver and lowered egg production [19].

Sex and age of animals have also an influence on $\mathrm{AFB}_{1}$ susceptibility. For instance, males are more susceptible than females and young animals of all species are more susceptible than mature animals to the effects of aflatoxin $[12,16]$. Feed refusal, reduced growth rate and decreased feed efficiency are the predominant signs of chronic aflatoxin poisoning. In addition, listlessness, weight loss, rough hair coat and mild diarrhea may occur. Anemia along with bruises and subcutaneous hemorrhage are also symptoms of aflatoxicosis. The disease may also impair reproductive efficiency, including abnormal estrous cycles (too short and too long) and abortions. Other symptoms include impaired immune system response, increased susceptibility to disease, and rectal prolapse [12].

A study identified and quantified aflatoxins $\left(\mathrm{AFB}_{1}, \mathrm{AFB}_{2}, \mathrm{AFG}_{1}\right.$ and $\left.\mathrm{AFG}_{2}\right)$ from poultry feed and their recovery, together with their metabolites $\left(\mathrm{AFM}_{1}, \mathrm{AFM}_{2}, \mathrm{AFP}_{1}\right.$ and aflatoxicol) in litter. Hens were divided in 3 groups and fed with $2 \mathrm{AFB}_{1}$ concentrations: 30 and $500 \mathrm{ppb}$, besides the control group. Feed samples of the 3 groups presented significant difference with $\mathrm{AFB}_{2}$ and $\mathrm{AFG}_{2}$, whereas in litter samples, there were significant differences for $\mathrm{AFG}_{2}$ in the $500 \mathrm{ppb}$ group. Poultry litter had traces of $\mathrm{AFM}_{1}, \mathrm{AFM}_{2}, \mathrm{AFP}_{1}$ (can be considered as a demethylated $\mathrm{AFB}_{1}$ ) and aflatoxicol with no significant differences among treatments [20].

The presence of molds in foodstuffs causes the appearance of flavors and odors that reduce palatability and affect feed consumption by animals as well as reduce the nutritional value of foods. Mycotoxins, in turn, affect the digestion and metabolism of nutrients in animal production, resulting in nutritional and physiological disorders, besides a negative effect on the immune system [21].

It was reported main effects caused by aflatoxins during swine growth and termination phases. When feed was contaminated with 10-100 ppb, productivity losses without noticeable clinical signs were observed. When this level was 200-400 ppb, reduced growth and feed efficiency occurred. At 400-800 ppb of aflatoxins in feed, there were liver diseases (friable or yellow-tan liver). After 800-1200 ppb of aflatoxins administration in feed, reduction of food intake and growth was observed. Finally, at 1200-2000 ppb, jaundice, coagulopathy, anorex- 
ia and even mortality may happen. Not only swine is affected by aflatoxins but all species, being the main clinical signs and lesions reported as decreased weight gain, digestive disorders, liver disease, anorexia, ataxia, tremors and death [22].

A total of 480 poultry feed samples from Rio de Janeiro state were collected monthly during one year and analyzed, being the main fungal species found P. citrinum (35\% of the samples) followed by A. flavus (25\%) which is the main aflatoxin producer microorganism. $\mathrm{AFB}_{1}$ levels ranged from 1.2 to $17.5 \mathrm{ppb}$. There were no significant differences $(\mathrm{P}<0.001)$ between all months tested except February and March when the highest and lowest $\mathrm{AFB}_{1}$ production was found [23]. In Pakistan, a total of 216 samples of poultry feed ingredients were assayed, being found maximum $191.65 \mathrm{ppb}$ for $\mathrm{AFB}_{1}, 86.85 \mathrm{ppb}$ for $\mathrm{AFB}_{2}, 89.80 \mathrm{ppb}$ for $\mathrm{AFG}_{2}$ and $167.82 \mathrm{ppb}$ for $\mathrm{AFG}_{1}$. Minimum aflatoxins were produced in the winter season. The temperature varies from 10 to $45^{\circ} \mathrm{C}$ in this country, favorable to Aspergillus growth [24].

Recently [25], a survey reported the association of mycotoxins with hematological and biochemical profiles in broilers. The authors performed meta-analysis using data from 98 articles, totaling 37,371 broilers. Some conclusions of this review were that mycotoxins reduced $(\mathrm{P}<0.05)$ the hematocrit $(-5 \%)$, hemoglobin $(-15 \%)$, leukocytes $(-25 \%)$, heterophils $(-2 \%)$, lymphocytes $(-2 \%)$, uric acid $(-31 \%)$, creatine kinase $(-27 \%)$, creatinine $(-23 \%)$, triglycerides $(-39 \%)$, albumin $(-17 \%)$, globulin $(-1 \%)$, total cholesterol $(-14 \%)$, calcium $(-5 \%)$, and inorganic phosphorus $(-12 \%)$. Mycotoxins also altered $(\mathrm{P}<0.05)$ the concentrations of alkaline phosphatase, alanine aminotransferase and aspartate aminotransferase. The total protein concentration in blood was $18 \%$ lower $(\mathrm{P}<0.05)$ in broilers challenged by aflatoxins compared with that of the unchallenged ones. The inclusion of antimycotoxin additives in diets with aflatoxins altered $(\mathrm{P}<0.05)$ some variables (uric acid, creatinine, alkaline phosphatase, alanine aminotransferase, aspartate aminotransferase, and $\gamma$-glutamyl transferase) in relation to the group that received diets with the mycotoxin and without the additive.

Another recent study assumes that aflatoxins could compromise the macrophages functions; in particular, co-exposure to $\mathrm{AFB}_{1}, \mathrm{AFB}_{2}, \mathrm{AFM}_{1}$ and $\mathrm{AFM}_{2}$ may exert interactions which can significantly affect immunoreactivity [26].

\section{Aflatoxins occurrence in animal products}

When focusing on how mycotoxins play a role in food safety, attention should be limited to mycotoxins that are known to be transferred from feed to food of animal origin, as this food represents a significant route of exposure for humans [27]. Apart from their toxicological effects in affected animals, the carry-over through animal derived products, such as meat, milk and eggs into the human food chains is an important aspect of mycotoxin contamination. FAO has estimated that up to $25 \%$ of the world's food crops and a higher percentage of the world's animal feedstuffs are significantly contaminated by mycotoxins.

Aflatoxin or ochratoxin residues in meat are uncommon and rarely found [28]. However, it's more common in organs especially liver. This organ may have its lipid content increased over three fold when 20 ppm aflatoxin is incorporated in broiler feed [29]. 
The problem in the egg production is that the long-term or short-term hen's exposure, via dietary sources, to low concentrations of certain mycotoxins causes contamination of eggs. This is the case of aflatoxins, which have a high impact in both, human and animal health, causing significant losses in the egg industry, considering the deleterious effect on egg production and quality.

In laboratory studies it was proved that aflatoxin can decrease egg production and increase liver fat (fatty liver syndrome). This classical study established the typical symptoms associated with acute or chronic aflatoxicosis, observed until today in field conditions [30].

A distinctive sequence of events during acute aflatoxicosis in laying hens (30 weeks-old) in a four week experiment with increasing aflatoxin doses in the diet of $0 ; 1.25 ; 2.5 ; 5.0$ and 10.0 $\mu \mathrm{g} \mathrm{g}^{-1}$ [31]. Results indicated that egg production was decreased by about $70 \%$ from the control value at $10 \mu \mathrm{g} \mathrm{g}^{-1}$ concentration in the diet and the liver size was increased significantly by 5 and $10 \mu \mathrm{g} \mathrm{g}^{-1}$ dietary concentrations of aflatoxin and the liver lipid increasing dramatically by a smaller dose of $2.5 \mu \mathrm{g} \mathrm{g}^{-1}$. Table 3 shows the dramatic effect of aflatoxin in the liver function [31]. The obtained data suggest that plasma and yolk lipids respond to the inhibition of lipid synthesis and transport from the liver during aflatoxicosis induced by the dietary treatments. The liver malfunction results in an increase in its fat content and a decrease in the levels of plasma lipids.

\begin{tabular}{ccc}
\hline Dose $\left(\boldsymbol{\mu} \boldsymbol{g ~}^{-1}\right)$ & Liver lipids (\%) & Plasma lipids $\left(\boldsymbol{g}^{\mathbf{1}} \mathbf{1 0 0} \boldsymbol{~}^{-1}\right)$ \\
\hline 0.0 & $21.2 \pm 1.1$ & $2.6 \pm 0.3$ \\
\hline 1.25 & $24.4 \pm 1.8$ & $2.6 \pm 0.4$ \\
\hline 2.5 & $32.7 \pm 1.8$ & $2.1 \pm 0.2$ \\
\hline 5.0 & $35.6 \pm 4.9$ & $1.9 \pm 0.1$ \\
\hline 10.0 & $46.5 \pm 4.7$ & $1.7 \pm 0.2$ \\
\hline
\end{tabular}

Adapted from ref. [31]. Values are means \pm Standard error of the mean

Table 3. Response of liver lipid and plasma lipid during aflatoxicosis in laying hens.

Zaghini et al. [32] supported the previous finding showing the effects of $\mathrm{AFB}_{1}$ on egg quality and chemical parameters. In the study, 44 weeks-old laying hens were submitted to a diet containing $2.5 \mathrm{ppm}$ of $\mathrm{AFB}_{1}$ and by the end of the second and third weeks of the trial, changes were observed like decreased egg weight (from $73.76 \mathrm{~g}$ to $72.5 \mathrm{~g}$, week $0-4^{\text {th }}$, respectively) and reduced shell weight, as indicated by the decline in the percent shell of eggs laid by the hens fed the $\mathrm{AFB}_{1}$ contaminated diet from $10.49 \%$ to $10.19 \%$. In the same study, aflatoxin also influenced color parameters, which were probably related to interference of $\mathrm{AFB}_{1}$ with lipid metabolism and pigmentary substances deposition in yolk. Additionally, all livers collected from the hens administered the mycotoxin group were positive for $\mathrm{AFB}_{1}$.

Astonishingly, as little as $0.2 \mathrm{mg} \mathrm{kg}^{-1}$ (or $0.2 \mathrm{ppm}$ ) of the metabolite $\mathrm{AFB}_{1}$ has been documented to reduce egg production and egg mass in laying hens from 22 to 40 weeks of age 
[33]. The most important economic effect of poultry ingesting AF-contaminated feed would be the increase of the mortality index [34] and in addition, aflatoxins intake can decrease productivity due to hepatic [35]; immunological [36] and renal damages [37].

In a detailed study focusing on the effects of aflatoxin chronic intoxication in renal function of laying hens (13 weeks-old), aflatoxins were evident at 17 weeks of the intoxication period. Final concentrations were $0,0.46,0.98$ and $1.53 \mathrm{mg}$ of aflatoxins per $\mathrm{kg}$ of feed, respectively and birds ingested the contaminated diets during 17 and 42 weeks. Body weight of intoxicated hens, showed a tendency to decrease, being significant in 1.0 and $1.5 \mathrm{mg} \mathrm{kg}^{-1}$ of feed concentrations in both times of the intoxication period. Evidence of tubular damage in kidney was found as a result of a decreased concentration of $\mathrm{Ca}^{++}$and $\mathrm{PO}_{4}{ }^{+3}$ in plasma or even a decreased $\mathrm{Ca}^{++} \mathrm{ab}-$ sorption from the gut. Also, microscopic lesions of glomerular and tubular structures like inflammatory and degenerative processes of the renal structures in hens kidneys were found. Additionally, the authors pointed out that the renal lesions occurred more frequently in larger doses of AF and over a long period of exposure to the toxin (42 weeks intoxication period) [38].

Other authors concluded that aflatoxins may have direct or indirect effect or both, on functionality of the gastrointestinal tract. Results indicated that specific activity of the intestinal maltase and disaccharidase increased quadratically, by feeding up to $1.2 \mathrm{mg} \mathrm{kg}^{-1}$ aflatoxins and declined at $2.5 \mathrm{mg} \mathrm{kg}^{-1}$ concentration in the study and the intestinal crypt depth (but not villus length) increased linearly with increasing the level of aflatoxins in the experimental diets [39].

Hens were fed three levels of aflatoxin that might approximate contamination under field conditions [40]. Pure $\mathrm{AFB}_{1}$ was prepared and mixed in the diet as follows: 0.1 ppm for 10 days; 0.2 ppm for 12 days and 0.4 ppm for 15 days. Results confirmed that $\mathrm{AFB}_{1}$ fed to hens was transmitted into eggs in measurable amounts at all levels and was found in both, albumen and yolks. The average amounts of aflatoxin distributed between albumen and yolk were 2.2 and $3.6 \mathrm{ppb}$, respectively. Even at the concentration of $0.1 \mathrm{ppm}$ of $\mathrm{AFB}_{1}$ in the layer diet, the transmission into eggs occurred as an average of $0.23 \mathrm{ppb}$.

Mainly aflatoxins and ochratoxin A may be found as residues at significant levels in muscles and muscle foods when contaminated feed is distributed to farm animals. Meat contamination may also result from toxigenic mold development during ripening and ageing. In muscles, only low levels are found, often below detection limits of the methods used, even after exposure of the animals to high doses of $\mathrm{AFB}_{1}$. In ruminants, many studies evaluated aflatoxin transfer into the milk of lactating cows. However, as for other species, residues can be found in liver and kidney that are edible parts of these animals [41].

It was reported [41] that processing conditions during ageing of hams may allow aflatoxin synthesis. Thus, is important to conduct research evaluating the production of $\mathrm{AFB}_{1}$ during meat processing and ageing. Studies show that frequency of processed meat contamination with $\mathrm{AFB}_{1}$ was low and the toxin level within meat was usually $<10 \mathrm{ng} \mathrm{g}^{-1}(\mathrm{ppb})$. It is not clear whether $\mathrm{AFB}_{1}$ was produced during meat processing or was present before at the residual level in muscles. The contamination of spices and additives added during meat processing may also represent a source of mycotoxin. Besides, spice addition may lead to a secondary contamination of the final product with aflatoxins. 
Table 4 shows residues of one or more aflatoxins in different hen tissues.

\begin{tabular}{|c|c|c|c|c|c|}
\hline Animal species & $\begin{array}{c}\text { Dose or exposure } \\
\text { time }\end{array}$ & Tissues & Residues $\left(\mu \mathrm{g} \mathrm{kg}{ }^{-1}\right)$ & Metabolites & Reference \\
\hline \multirow[t]{5}{*}{ Laying hens } & $2.5 \mathrm{ppm} \mathrm{AFB}{ }_{1}$ in & Muscle & $0.08 \pm 0.03$ & & \\
\hline & feed for 4 weeks & Eggs & $0.24 \pm 0.07$ and & & \\
\hline & & & $0.25 \pm 0.09$ & & [32] \\
\hline & & Liver & $4.13 \pm 1.95$ & & \\
\hline & & Eggs & $<0.5$ and $<0.01$ & & \\
\hline \multirow[t]{13}{*}{ Layer breeder hens } & $\begin{array}{c}\mathrm{OTA}+\mathrm{AFB}_{1} \\
\mathrm{mg} \mathrm{kg}^{-1}\end{array}$ & & & & \\
\hline & $0+0$ & Liver/Muscle/ & $N D+N D$ & & \\
\hline & & Kidney & & & \\
\hline & & Muscle & $N D+0.03$ & & \\
\hline & $0+5$ & Kidney & $N D+0.25$ & & \\
\hline & & Liver & $N D+1.44$ & & \\
\hline & & & & $\mathrm{OTA}+\mathrm{AFB}{ }_{1}$ & {$[42]$} \\
\hline & & Muscle & $0.34+0.02$ & & \\
\hline & $3+5$ & Kidney & $2.80+0.27$ & & \\
\hline & & Liver & $1.98+0.26$ & & \\
\hline & & Muscle & $0.51+0.02$ & & \\
\hline & $5+5$ & Kidney & $2.81+0.27$ & & \\
\hline & & Liver & $2.21+0.11$ & & \\
\hline
\end{tabular}

Table 4. Residues of aflatoxin in animal products combined or not with other mycotoxin.

Feeding one mycotoxin alone (OTA) resulted in significantly higher residue levels in liver, kidney and breast muscles of hens than their counterpart birds kept on a diet concurrently contaminated with both OTA and $\mathrm{AFB}_{1}$ [42]. In this study, a total of 72 White Leghorn layer breeder hens at 45 weeks of age were submitted to diets containing different combinations of these mycotoxins (some are shown in Table 4, focusing mainly on $\mathrm{AFB}_{1}$ residues). In liver of hens fed OTA alone at $5 \mathrm{mg} \mathrm{kg}^{-1}(\mathrm{ppm})$ feed, residues level was $22.54 \pm 1.48$ (mean $\pm \mathrm{SD}$ ) ppb, as compared to significantly lower residual concentration of $2.21 \pm 0.42$, in the same levels of OTA when administered in combination with $\mathrm{AFB}_{1}$. Residues of OTA were significantly higher in liver than in kidneys of the hens fed OTA alone, in all experimental groups. However, feeding OTA in combination with $\mathrm{AFB}_{1}$ resulted in higher deposition of OTA in kidneys than in livers. Residues of $\mathrm{AFB}_{1}$ were significantly higher in liver and breast muscles of the birds kept on $\mathrm{AFB}_{1}$ contaminated feed compared with those fed OTA and $\mathrm{AFB}_{1}$ concurrently. When the maximum dosage (5 ppm) was administered, residues of OTA and $\mathrm{AFB}_{1}$ were also the maximum in the 
liver, i.e. $22.54 \pm 1.48$ and $1.44 \pm 0.21 \mathrm{ppb}$, respectively, while a minimum concentration of residues of both mycotoxins was found in the breast muscles of the laying hens. Residues of $\mathrm{AFB}_{1}$ in the eggs appeared at day 5 of toxin feeding and disappeared at day 6 of withdrawal of $\mathrm{AFB}_{1}$ contaminated diet. As in case of tissues, residues of OTA and $\mathrm{AFB}_{1}$ are significantly lower in eggs obtained from hens fed both toxins in combination, compared to those fed each mycotoxin alone, possibly due to their protein binding potentials.

Another study shows that concentration of $\mathrm{AFB}_{1}$ residues in liver and muscles increased with toxin ingestion time and were at its highest levels (6.97 ppb in liver and $3.27 \mathrm{ppb}$ in muscle) on the last day $\left(7^{\text {th }}\right)$ of feeding $\mathrm{AFB}_{1}$ contaminated ration. Broiler chicks of 7,14 and 28 days of age fed same level of $\mathrm{AFB}_{1}$ showed lower tissue residues in older birds compared with younger ones. Birds given 1600 and 3200 ppb AFB $_{1}$ for 7 days at 28 days of age had no detectable $\mathrm{AFB}_{1}$ levels in liver and muscles after 3 and 8 days of withdrawal of contaminated feed. A rapid decrease in $\mathrm{AFB}_{1}$ residues below the tolerance limits from muscles and liver within 3 and 7 days of withdrawal of dietary $\mathrm{AFB}_{1}$ in this study confirm the rapid metabolism of aflatoxins in the body of chicken and that it may not become a significant human health risk. However, in areas with no regulatory limits on $\mathrm{AFB}_{1}$ levels of poultry feed, the secondary exposure to aflatoxins through consumption of chicken liver and meat derived from the poultry fed contaminated feed may pose a risk to consumers health [43].

\begin{tabular}{lcccc}
\hline \multicolumn{1}{c}{ Product } & Aflatoxin & Positive/total of samples & Range (ppb) & Method \\
\hline Corn & $\mathrm{AFs}$ & $76 / 246$ & $2-906$ & TLC or ELISA \\
\hline Corn & $\mathrm{AFB}_{2}$ & $33 / 292$ & $1-17$ & TLC \\
\hline Feed & $\mathrm{AFB}_{1}$ & $14 / 96$ & $11-287$ & $\mathrm{TLC}$ \\
\hline Eggs & $\mathrm{AFB}_{1}$ & $2 / 210$ & $2-5$ & $\mathrm{TLC}$ \\
\hline Eggs & $\mathrm{AFM}_{1}$ & $0 / 210$ & - & $\mathrm{TLC}$ \\
\hline Swine liver & $\mathrm{AFB}_{1}$ & $1 / 43$ & 27 & $\mathrm{TLC}$ \\
\hline Chicken liver & $\mathrm{AFB}_{1}$ & $3 / 6$ & $1.2-3.2$ & $\mathrm{TLC/HPLC}$ \\
\hline
\end{tabular}

Table 5. Mycotoxin levels in vegetable and animal products. Adapted from ref. [45]. See this review to obtain the references of original publication.

The impact of subchronic exposure of $\mathrm{AFB}_{1}$ on the tissue residues of enrofloxacin and its metabolite ciprofloxacin was examined in broilers. Broiler chickens given either normal or $\mathrm{AFB}_{1}$ (750 ppb diet) supplemented diets for 6 weeks received enrofloxacin $\left(10 \mathrm{mg} \mathrm{kg}^{-1}\right.$ day $^{-1}$, p.o.) for 4 days and thereafter, residue levels were determined at 1, 5 and 10 days after the last treatment. In $\mathrm{AFB}_{1}$-unexposed broiler chickens, enrofloxacin was detected in all the tissues. After $24 \mathrm{~h}$ of treatment cessation, concentrations of enrofloxacin were up to $0.85 \mu \mathrm{g} \mathrm{g}^{-1}$ in the following order: liver $>$ skin+fat $>$ muscle $>$ kidney. The parent drug was not found in any of the tissues except liver 10 days after the last dose of enrofloxacin. Ciprofloxacin was not detectable in any tissue. In $\mathrm{AFB}_{1}$-exposed broiler chickens, higher concentrations of enrofloxacin and ciprofloxacin were found in different tissues, compared with tissues of control broiler chickens. After $24 \mathrm{~h}$ of the last dose of enrofloxacin, concentrations up to $4.53 \mu \mathrm{g} \mathrm{g}{ }^{-1}$ were found of the parent drug in the order skin+fat>liver>kidney>muscle. The parent drug 
persisted in all the tissues except muscle for 10 days. Ciprofloxacin was detected in muscle and skin plus fat $24 \mathrm{~h}$ after termination of enrofloxacin administration and it persisted only in muscle for 10 days. The metabolite was not detectable in kidney [44].

A review carried out in Brazil [45] showed high variability among the results (Table 5). For instance, corn contamination with aflatoxins reached $906 \mathrm{ppb}$, above those levels allowed by legislation $(20 \mathrm{ppb})$. This fact indicates the need for quality control in the reception of this ingredient in the feed mill with the use of rapid tests for mycotoxins. Regarding products of animal origin, major problems were not observed in eggs and tissues of swine and poultry (Table 5). However, among chicken liver samples 50\% tested positive but with relatively low levels. Anyway, attention should be paid with liver consumption when there are evidences of corn contamination. From Table 5 data, it can be noted that contaminated feed samples achieved up to $287 \mathrm{ppb} \mathrm{AFB}_{1}$, above values allowed by legislation.

A survey with hens fed $\mathrm{AFB}_{1}$ via moldy rice powder feed showed residues in eggs and tissues (kidneys, liver, muscle, blood, and ova) [46]. Hens were fed for 7 days with a contaminated diet $\left(8 \mu \mathrm{g} \mathrm{g}^{-1}\right)$ followed by additional 7 days on an aflatoxin-free diet. Eggs were collected over the entire 14-day period. The study showed that aflatoxicol (R0), a carcinogenic metabolite of $\mathrm{AFB}_{1}$, was found in all samples but blood (Table 6). Levels of R0 and $\mathrm{AFB}_{1}$ were approximately the same in eggs, ova, kidneys, and liver. In eggs, the levels of R0 and $\mathrm{AFB}_{1}\left(0.02\right.$ to $\left.0.2 \mathrm{ng} \mathrm{g}^{-1}\right)$ increased steadily for 4 or 5 days until reaching a plateau and then decreased after $B_{1}$ withdrawal at the same rate as they increased. After 7 days of withdrawal, only trace amounts of R0 $\left(0.01 \mathrm{ng} \mathrm{g}^{-1}\right)$ remained in eggs. All samples from hens sacrificed immediately before aflatoxin withdrawal contained $\mathrm{R} 0$ or $\mathrm{R} 0+\mathrm{AFB}_{1}$. R0 was the only aflatoxin detected in muscle. Seven days after aflatoxin withdrawal, $B_{1}\left(0.08 \mathrm{ng} \mathrm{g}^{-1}\right)$ was found in one of nine livers and R0 (0.01-0.04 $\left.\mathrm{ng} \mathrm{g}^{-1}\right)$ in eight of nine muscles analyzed, but no aflatoxins were found in any other tissues. Interestingly, the transfer of aflatoxins into eggs is right after administration, since $B_{1}\left(0.03 \mathrm{ng} \mathrm{g}^{-1}\right)$ and $\mathrm{R} 0\left(0.02 \mathrm{ng} \mathrm{g}^{-1}\right)$ residues were found in eggs laid 1 day after contaminated feed was administered. This indicates that toxins penetrate the egg through eggwhite since yolk was already formed before this period. Aflatoxin apparently can enter the egg at any stage of its development. This is because it takes 7 to 8 days for each oocyte to develop into a mature ovum (yolk) and 24 hours for the egg oviposition.

\begin{tabular}{lccc}
\hline Tissue & $\boldsymbol{R O}$ & $\boldsymbol{A F B}_{\mathbf{1}}$ & $\boldsymbol{A F M}_{\boldsymbol{1}}$ \\
\hline Ova & 0.25 & 0.24 & ND \\
\hline Kidneys & 0.10 & 0.25 & 0.05 \\
\hline Liver & 0.20 & 0.46 & ND \\
\hline Muscle & 0.08 & ND & ND \\
\hline Blood & ND & 0.05 & 0.10 \\
\hline
\end{tabular}

Table 6. $\mathrm{AFB}_{1}$ and its metabolites aflatoxicol $(\mathrm{RO})$ and $\mathrm{AFM}_{1}\left(\mathrm{ng} \mathrm{g}^{-1}\right)$ after contaminated diet ingestion with $\mathrm{AFB}_{1}(8 \mu \mathrm{g}$ $\left.\mathrm{g}^{-1}\right)$. Values in $\mathrm{ppb} ; \mathrm{ND}=$ Not detected [46]. 


\section{Legislation in feed and feed ingredients}

In the last decades, only aflatoxins and, to a lesser extent, ochratoxin A were regulated in foods from animal origin. For other toxins, the risk management was based on the control of the contamination of food from vegetal origin intended for both human and animal consumption. Nowadays, other mycotoxins are included. Regulatory values or recommendations are mainly built on available knowledge on toxicity and potential carryover of these molecules in animal. Therefore, by limiting animal exposure through feed ingestion, one can guarantee against the presence of residues of mycotoxins in animal-derived products. However, accidental high levels of contamination may lead to a sporadic contamination of products coming from exposed animals [41].

Tolerance levels of mycotoxins in foods are needed to ensure product quality and consumer health. The limits differ among countries, i.e., depending on the product and the country there are different tolerance levels for each mycotoxin, but it is certain that their presence in foods has been widely researched and new standards were required over the years, in the last decade. Table 7 shows an average of mycotoxin variation depending on the type of food, required as maximum standard in different countries.

\begin{tabular}{lccc}
\hline Mycotoxins* $^{*}$ & Feed $^{1}$ & Corn $^{2}$ & Soybean $^{\mathbf{3}}$ \\
\hline Aflatoxin $\mathrm{B}_{1}, \mathrm{ppb}$ & $1.5-50$ & $1-50$ & $30-50$ \\
\hline Aflatoxin $\mathrm{B}_{1}, \mathrm{~B}_{2}, \mathrm{G}_{1}$ and $\mathrm{G}_{2}, \mathrm{ppb}$ & $0-75$ & $5-50$ & $20-50$ \\
\hline Deoxynivalenol, ppb & $5-1500$ & - & - \\
\hline Toxin HT2, ppb & $25-100$ & - & - \\
\hline Ochratoxin, ppb & $5-300$ & $50-300$ & - \\
\hline Zearalenone, ppb & - & $0.5-200$ & - \\
\hline
\end{tabular}

${ }^{1}$ Relative to feed and concentrates for all categories and phases of animal

${ }^{2}$ Corn and byproducts

${ }^{3}$ Soybean and byproducts

* Source: Adapted from Resolution RDC N07 [47] and EUR-LEX [48].

Table 7. Variation among different countries regarding maximum tolerance limits of mycotoxins.

In Brazil, the most recent resolution on mycotoxins in food is the RDC 07/2011 [47] which establishes maximum tolerated levels for aflatoxins $\left(\mathrm{AFB}_{1}+\mathrm{AFB}_{2}+\mathrm{AFG}_{1}+\mathrm{AFG}_{2}\right.$ and $\mathrm{AFM} \mathrm{M}_{1}$ ), ochratoxin $\mathrm{A}$, deoxynivalenol, fumonisins $\left(\mathrm{FB}_{1}+\mathrm{FB}_{2}\right)$, patulin and zearalenone, admissible in ready-to-eat foods and raw materials. To adapt to the new standard required in 2011, the producers of 14 food categories should meet the requirements until 2016. Table 8 shows standard values set for corn, which is the main ingredient added to feed in the country.

Brazil, like different countries, also follows the recommendation to keep mycotoxin levels as low as possible. For that, better practices and technologies in the production, handling, stor- 
age, processing and packaging should be accomplished in order to prevent that contaminated food is sold or consumed.

\begin{tabular}{lc}
\hline Mycotoxins & Corn and byproducts* \\
\hline Aflatoxins $\mathrm{B}_{1}, \mathrm{~B}_{2}, \mathrm{G}_{1}$ and $\mathrm{G}_{2}, \mathrm{ppb}$ & 20 \\
\hline Deoxynivalenol, $\mathrm{ppb}$ & 3000 \\
\hline Fumonisin $\mathrm{B}_{1}+\mathrm{B}_{2}, \mathrm{ppb}$ & 5000 \\
\hline Zearalenone, ppb & 400 \\
\hline
\end{tabular}

Table 8. Maximum tolerated levels for mycotoxins according to Resolution RDC 07/2011 [47].*The maximum tolerated levels refer to results obtained by methodologies that comply with the performance criteria established by Codex Alimentarius.

\section{Aflatoxin binders and strategies to reduce toxicity to farm animals}

Adsorbents are necessary and important and may have great impact on improving animal production and health, providing greater security to consumers of animal products, due to the reduction and/or removal of mycotoxins in these products.

Considering that aflatoxins were the first discovered mycotoxins, there are many data available searching for binders and other methods to reduce toxicity in animals. However, due to methodologies used for evaluation, there is certain degree of variation in results.

The most common additives used in animal diets are aluminosilicates, produced synthetically or extracted from clay mines. There are also other alternatives to reduce aflatoxin toxicity, as presented.

\section{a. Clay derived sorbents:}

This type of binder is basically composed by single or blended type of clay. The most common clay is hydrated sodium calcium aluminosilicate (HSCAS). However, there are other sort of clays which can be used as toxin binders, like sodium or calcium bentonites and zeolites. Not often, any particular varying sort of clay can be used as well. It has to be considered that such materials can be synthesized industrially or obtained from mines around the world. In the case of natural sources (mines) it has to be considered that each source may present specific particularities in terms of composition, which can impact the binding capacity, and even clays obtained from the same place, can vary from batch to batch, that has to be well controlled throughout quality control.

There is much information available in the literature comparing those different clays [49]. These authors for example, compared zeolite, bentonite and HSCAS for AFB $_{1}$ binding capacity using in vitro method, simulating gastrointestinal fluids. This method seems to be the most frequent technology adopted for such assays, including a double condition of $\mathrm{pH}$ (3.0 and 7.0). 
Those researchers find that zeolite and bentonite aflatoxin binding capacity varied according to the $\mathrm{pH}$ used for the assay, and both clays were less effective than HSCAS (Figure 2).

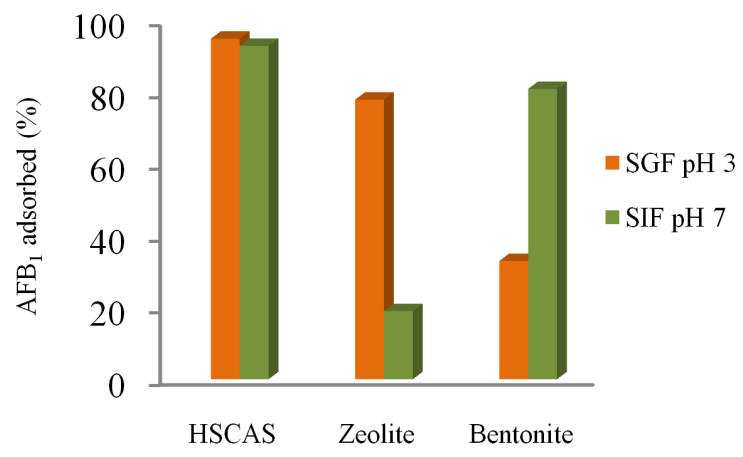

Figure 2. Adsorption percentage of $\mathrm{AFB}_{1}(8 \mu \mathrm{g} / \mathrm{ml})$ to sorbents $(0.5 \% \mathrm{w} / \mathrm{v})$ in simulated gastrointestinal fluid at $\mathrm{pH} 3$ and $\mathrm{pH} 7$ [49].

It is important to establish the correct inclusion rate to animal diets in order to optimize the binding response. In Figure 3, it can be observed how those three types of clays perform under the same $\mathrm{pH}(7.0)$ when increasing doses are included.

It has been shown that montmorillonite $(0.5 \%)$ added to the diet containing 5 ppm of aflatoxin has proven its effectiveness in preventing the effects of aflatoxicosis in broilers [50].

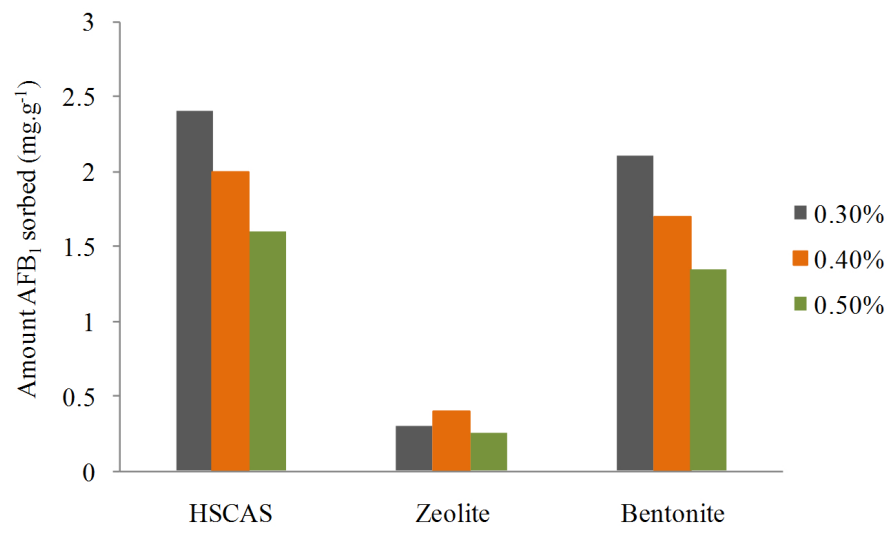

Figure 3. Amount of aflatoxin $B_{1}$ adsorbed on sorbents at different concentrations of the adsorbents in simulated intestinal fluid at $\mathrm{pH} 7$ [50].

Based on the data presented in Figures 2 and 3, it is clear that assays condition (especially $\mathrm{pH}$ ) and toxin:sorbent dosing rate are extremely important. These conditions should be considered when product performance reports are compared. However, when evaluating [51] nine different toxin binders ( 4 activated charcoals, 3 sodium bentonites, 1 calcium bentonite 
and 1 esterified glucomannan) all products presented adsorption above $95 \%$ of $\mathrm{AFB}_{1}$, regardless of the $\mathrm{pH}$ used (3.0, 7.0, 10.0 and the original $\mathrm{pH}$ of each product).

Other methods can be used to evaluate toxin adsorbents, as in vivo trials. In this case, the most frequent inconsistency when comparing research reports is related to the source used to obtain aflatoxin (synthetic crystalline vs natural aflatoxin obtained by fermentation) and also the aflatoxin level used in the specific assay. When comparing analytical reports with field accepted levels of aflatoxins, there is much difference. One reason for that is the difference between the experimental conditions (well controlled) where animals are not submitted to stress situation in comparison to the real farm condition.

Another additional evaluation that should be performed is the presence of aflatoxin in specific organs, like liver. Low level of $\mathrm{AFB}_{1}(50 \mathrm{ppb})$ on broiler performance was studied on biochemical parameters and aflatoxin presence in liver tissue, when monensin and sodium bentonite were added to the feed, from 18 up to 46 days of age. The authors concluded that monensin and $\mathrm{AFB}_{1}$ compete for adsorption sites on sodium bentonites, indicating a non-selective adsorption capacity of this particular binder. The researchers comment as well that different substances, such as coccidiostats, vitamins, minerals, aminoacids or other dietary components, could affect the ability of the adsorbent to bind low levels of aflatoxin. In addition, significant levels of $\mathrm{AFB}_{1}$ in livers indicate that this determination is important not only for diagnosis of aflatoxicosis in broilers, but also for quality control of avian products [52].

\section{b. Organic sorbents:}

The most well-known natural toxin binders are yeast based products. Glucans are yeast cell wall constituents. Those compounds have been submitted to esterification process generating a new additive with toxin binding capacity, called esterified glucomannan (EGM). Efficacy of EGM was tested against mycotoxins naturally present in broiler feed [53], being 0.05\% EGM efficient to counteract the adverse effects of mycotoxins (Table 9).

\begin{tabular}{ccccc}
\hline Mycotoxin $^{*}$ & EGM (\%) & $\boldsymbol{L W}(\boldsymbol{g})$ & $\boldsymbol{F I}(\boldsymbol{g})$ & $\boldsymbol{F C R}\left(\boldsymbol{g} \boldsymbol{g}^{-1}\right)$ \\
\hline--- & ---- & $1,391.2^{\mathrm{b}}$ & $3,017.6^{\mathrm{b}}$ & $2.17^{\mathrm{b}}$ \\
\hline--- & 0.05 & $1,441.4^{\mathrm{c}}$ & $2,994.0^{\mathrm{b}}$ & $2.07^{\mathrm{a}}$ \\
\hline+++ & --- & $1,258.8^{\mathrm{a}}$ & $2,803.4^{\mathrm{a}}$ & $2.22^{\mathrm{c}}$ \\
\hline+++ & 0.05 & $1,381.0^{\mathrm{b}}$ & $2,952.6^{\mathrm{b}}$ & $2.15^{\mathrm{b}}$ \\
\hline SEM & & 7.25 & 20.01 & 0.015 \\
\hline
\end{tabular}

* Aflatoxin 168 ppb, ochratoxin 8.4 ppb, zearalenone 54 ppb and T2-Toxin 32 ppb [53].

Table 9. Efficacy of esterified glucomannans (EGM) on broiler live weight (LW), feed intake (FI) and feed conversion ratio $(F C R)$ fed with a mycotoxin contaminated diet, from one up to 35 days.

\section{c. Other strategies:}

The use of mechanisms that improve animal health and physiology can be helpful. One example is the use of probiotics which have been used to ameliorate mycotoxicosis. Acti- 
vated charcoal has been used to prevent animal intoxication by several compounds, including mycotoxins. Plant extracts with specific mode of action, like liver protection, have been used as well to reduce the toxicity of some mycotoxins, specially aflatoxin.

Milk thistle (Silybum marianum), which is a medicinal herb found in Pakistan, has been used to treat liver diseases. This herb was tested in poultry feed contaminated with $\mathrm{AFB}_{1}(80 \mathrm{ppb}$ for the first week and $520 \mathrm{ppb}$ from the second until the fifth) at a dose of $1 \%$. The results indicated that milk thistle is effective as hepatoprotectant and growth promoter in the presence of $\mathrm{AFB}_{1}$ in the feed [54]. Protection against the negative effects of aflatoxin on performance of broiler chickens was observed when broilers were fed during 4 weeks with $0.05 \%$ ETE (ethanolic turmeric extract, Curcuma longa) plus 3 ppm aflatoxins [55].

Another report concluded that dietary citric acid supplementation can be used as an additive to degrade aflatoxins in the ration as well as to promote growth performance in young broiler chickens. Results showed that aflatoxins in the diet, at a concentration of $39 \mathrm{ppb}$ were almost degraded (92\%) by the acidification procedure (up to $50 \mathrm{~g} \mathrm{~kg}^{-1}$ ) [56].

Other alternatives to degrade aflatoxins have been tested, like the use of microorganism. Bacteria (Nocardia corynebacteroides, NC) showed ability to degrade $\mathrm{AFB}_{1}$ [57]. In a trial performed with broiler fed $\mathrm{AFB}_{1}(800-1,200 \mathrm{ppb}) \mathrm{NC}$ was safe to the birds and showed protection to the animal, indicating that it can be used as a tool to detoxify feed contaminated with $\mathrm{AFB}_{1}$ at high levels [58].

Humic acid, generated during matter decomposition, has binding capacity for many molecules. The use of oxihumate was evaluated as $\mathrm{AFB}_{1}$ binder, in vitro and in vivo [35]. Oxihumate showed a high in vitro affinity for $\mathrm{AFB}_{1}$. In vivo trial showed that oxihumate decreased adverse effects caused by $\mathrm{AFB}_{1}$ on broiler body weight and also protective effect against liver damage, stomach and heart hyperplasia, acting positively preserving standard blood parameters. Enzyme degradation of aflatoxin has been tested as well. Data suggest that lactoperoxidase can be used to hydrolyze aflatoxin [59].

\section{d. Other aspects:}

There are many contradictory data available in the main scientific journals. One and probably the main reason for that is the way the trials have been performed, differing in terms of toxin levels, and environmental condition of the trials. Under a real field condition, the challenges the animals suffer are far stronger then under experimental situation. Toxin binder, especially clays, may affect the cation binding capacity of feeds and consequently influencing water intake and feed consumption. Also, the effects of none, medium (1 $\mathrm{g}$ $\mathrm{kg}^{-1}$ feed) and high (2.5 $\mathrm{g} \mathrm{kg}^{-1}$ feed) inclusion levels of HSCAS was evaluated in broiler mycotoxin free diets [60]. The data suggest that increasing HSCAS to diets may modify performance, internal organ weights, gastrointestinal and biochemical parameters. However, other authors [61] did not see effect as the consequence of toxin binders (EGM) presence on broiler body weight and feed efficiency. 


\section{Detoxifying agents}

Mycotoxin $^{3}$

\begin{tabular}{|c|c|c|c|c|c|c|c|c|c|}
\hline & $\mathrm{AFB}_{1}$ & CPA & DAS & DON & $\begin{array}{l}\text { Fusaric } \\
\text { acid }\end{array}$ & NIV & OTA & $\begin{array}{c}\text { T2 } \\
\text { Toxin }\end{array}$ & ZEA \\
\hline HSCAS & + & - & & & & & - & - & \\
\hline Clinoptilolite & $+/-$ & - & & & & & & & \\
\hline Modified nanomontmorilonite & + & & & & & & & & \\
\hline Mg K aluminosilicate & $+/-$ & & & & & & & & \\
\hline Sodium bentonite & + & & & & & & & & \\
\hline Ca montmorillonite & + & & & & & & & & \\
\hline $\begin{array}{l}\text { Synthetic crystalline } \\
\text { aluminosilicate }\end{array}$ & $+/-$ & & & & & & & & \\
\hline Acidic phyllosilicate & & - & & & & & & & \\
\hline Zeolite & + & & - & & & - & & - & \\
\hline Diatomaceous earth & & & & & & & + & & \\
\hline Charcoal & & & & & & & - & & \\
\hline Superactivated charcoal & $+/-$ & & & & & & & $+/-$ & \\
\hline $\mathrm{BHT}^{1}$ & + & & & & & & & & \\
\hline $\begin{array}{l}\text { Cell wall Saccharomyces } \\
\text { cerevisiae }\end{array}$ & + & & & & & & & & \\
\hline Yeast glucomannans & + & & & & & & & & \\
\hline Esterified glucomannans & + & & & $+/-$ & + & & + & - & + \\
\hline Xylanase & & & & - & & & & & \\
\hline Live yeast culture residue & + & & & & & & & & \\
\hline Nocardia corynebacteroides & $+/-$ & & & & & & & & \\
\hline Eubacterium & & & + & + & & & & + & \\
\hline $\begin{array}{l}\text { Yeast Trichosporon } \\
\text { mycotoxinivorans }\end{array}$ & & & & & & & + & & - \\
\hline Saccharomyces cerevisiae & + & & & & & & & & \\
\hline Ammonia & + & & & & & & & & \\
\hline Calcium propionate & $+/-$ & & & & & & & & \\
\hline PVPP $^{2}$ & $+1-$ & & & - & & & & & \\
\hline
\end{tabular}

${ }^{1} \mathrm{BHT}=$ butylhydroxytoluene; ${ }^{2} \mathrm{PVPP}=$ Polyvinylpolypyrrolidone; ${ }^{3}$ Mycotoxins $\mathrm{AFB}_{1}=$ aflatoxin $\mathrm{B}_{1}, \mathrm{CPA}=$ cyclopiazonic acid; DAS = diacetoxyscirpenol, DON = deoxynivalenol; NIV = nivalenol, OTA = ochratoxin A, ZEA = zearalenone.

Cells highlighted in dark gray indicate that the product has shown positive effects in counteracting deleterious effects of mycotoxins, while light gray color depicts that the product was not effective.

+ : positive effect of the mycotoxin-detoxifying agent;

- : negative effect of the mycotoxin-detoxifying agent;

+/-: positive effect of the mycotoxin-detoxifying agent on some parameters, no effect on other parameters.

Table 10. Mycotoxin detoxifying agents tested in vivo in poultry. Adapted from ref. [62]. 
Additionally, different regions across the world have been dealing with mycotoxin subject in different ways. In US for instance, no toxin binders are officially registered, as a consequence of the control quality assumed for feedstuffs. In EU, since 2009, toxin sequestrants have been considered as a sort of feed additive, and a scientific group of specialists, namely European Food Safety Authority [62] have been working on re-evaluation of the efficacy and biological effects of detoxifying agents in animals. In Tables 10 and 11, a summary of the outcome of that technical group is presented.

\begin{tabular}{|c|c|c|c|c|c|c|}
\hline Detoxifying agents & $\mathrm{AFB}_{1}$ & DON-NIV & Fumonisin & OTA & T2 Toxin & ZEA \\
\hline HSCAS & + & - & & & & \\
\hline Montmorilonite & & - & & & & - \\
\hline Sodium bentonite & + & - & & & & \\
\hline Calcium bentonite & + & & & & & \\
\hline Zeolite & + & & & & & + \\
\hline Sepiolite & + & & & & & \\
\hline Palygorskite & + & & & & & \\
\hline Ammonium carbonate & & - & & & & \\
\hline Charcoal & & & $+/-$ & & & \\
\hline Polyvinylpolypyrrolidone & & - & & & & \\
\hline Yeast glucomannans & + & $+/-$ & & & - & + \\
\hline Apple pommace & & + & & & & \\
\hline Alfafa & & & & & & + \\
\hline Content of large intestine of hens & & + & & & & \\
\hline Eubacterium & & + & & & & \\
\hline Combination of Eubacterium BBSH & & - & & & & \\
\hline
\end{tabular}

Cells highlighted in dark gray indicate that the product has shown positive effects in counteracting deleterious effects of mycotoxins, while light gray color depicts that the product was not effective.

+: positive effect of the mycotoxin-detoxifying agent; -: negative effect of the mycotoxin-detoxifying agent;

+/-: positive effect of the mycotoxin-detoxifying agent on some parameters, no effect on other parameters.

Table 11. Mycotoxin detoxifying agents tested in vivo in pigs. Adapted from ref. [62].

In other regions, like South America, due to the climate and grain production conditions, mycotoxin has been a significant challenge along the past decades. This particular situation has been forcing the development of research groups which are involved with commercial sequestrants evaluation. As a consequence, the maximum acceptable aflatoxin limit has been established for different raw materials and feed, as well the specificity and inclusion levels of toxin binders in animal feed. However there are many different criteria for toxin adsorb- 
ents registration in different countries, some demanding an extend documentation about product efficacy and others are less restrictive.

\section{Conclusions}

There is a risk of contamination of meat products, eggs and milk with mycotoxins, although literature shows great variability due to the ingredients contamination which are included in feed. Ingredients should be analyzed before their entrance into the silo.

Mycotoxin contamination of ingredients used in feeds for broilers and laying hens is a reality in Brazil, since there are deficiencies in storage, handling and harvesting. Effects on animal production may vary depending on dose and time of administration and/or combination among mycotoxins which are not fully elucidated yet.

In general, mycotoxin residues tend to decrease rapidly after removal of the contaminated diet, which allows "to clean" broilers when feeding a diet free of mycotoxins few days before slaughter. This management option is not viable for laying hens and dairy cattle, since eggs and milk are generated continuously.

Apart from their toxicological effects in affected animals, the carry-over through animal derived products, such as eggs into the human food chains is an important aspect of aflatoxin contamination. Aflatoxins have a high impact in both, human and animal health, causing significant losses in the egg industry, considering the deleterious effect on egg production and quality. There is scarce literature in Brazil regarding egg contamination by aflatoxins.

After mycotoxin contamination of raw materials and feeds, effects can be minimized by using adsorbents which inhibit intestinal absorption of mycotoxins and can thereby prevent their deleterious effects in poultry production.

\section{Author details}

Vivian Feddern ${ }^{1 *}$, Giniani C. Dors ${ }^{2}$, Fernando de C. Tavernari ${ }^{1}$, Helenice Mazzuco ${ }^{1}$, Anildo Cunha Jr. ${ }^{1}$, Everton L. Krabbe ${ }^{1}$ and Gerson N. Scheuermann ${ }^{1}$

*Address all correspondence to: vivian.feddern@embrapa.br

1 Embrapa Suínos e Aves, Concórdia, SC, Brazil

2 Instituto Federal Catarinense (IFC) - Campus Concórdia, Concórdia, SC, Brazil 


\section{References}

[1] Ramos Girona, A. J., Sillué, S. M., \& Almenar, V. S. (2011). Micotoxinas. Introducción histórica. Ramos Girona AJ (ed.). Micotoxinas y micotoxicosis, Madrid, AMV Ediciones, $1-18$.

[2] Bakırdere, S., Bora, S., Bakırdere, E., Aydın, F., Arslan, Y., Komesli, O., et al. (2012). Aflatoxin species: their health effects and determination methods in different foodstuffs. Central European Journal of Chemistry, 10(3), 675-85.

[3] Atanda, S. A., Aina, J. A., Agoda, S. A., \& U. OE, P. PO. (2012). Mycotoxin Management in Agriculture: a Review. Journal of Animal Science Advances, 2(Suppl. 3.1), 250-60.

[4] Moss, M. O. (1996). Mycotoxins. Mycological Research, 100(5), 513-23.

[5] European Mycotoxins Awareness Network. (2012). The Aflatoxins. Available from, http://services.leatherheadfood.com/eman/Factsheet.aspx?ID=6, accessed 08 oct. 2012.

[6] IARC Monographs on the Evaluation of Carcinogenic Risks to Humans. (2002).

[7] Kussak, A., Andersson, B., \& Andersson, K. (1995). Determination of aflatoxins in airborne dust from feed factories by automated immunoaffinity column clean-up and liquid chromatography. Journal of Chromatography A, 708(1), 55-60.

[8] IARC Monographs on the Evaluation of Carcinogenic Risks to Humans. (2012). Agents Classified by the IARC Monographs, 1-105, Available from, http://monographs.iarc.fr/ENG/Classification/, accessed 28 June 2012.

[9] IARC Monographs on the Evaluation of Carcinogenic Risks to Humans. (2012). A Review of Human Carcinogens: Chemical Agents and Related Occupations, 100F, Available from, http://monographs.iarc.fr/ENG/Monographs/vol100F/mono100F-23.pdf, accessed 28 June 2012.

[10] IARC Monographs on the Evaluation of Carcinogenic Risks to Humans. (1993). Some Naturally Occurring Substances: Food Items and Constituents. Heterocyclic Aromatic Amines and Mycotoxins, 56.

[11] Papp, E., -Otta, K. H., Záray, G., \& Mincsovics, E. (2002). Liquid chromatographic determination of aflatoxins. Microchemical Journal, 73(1-2), 39-46.

[12] Cassel, E. K. , Campbell, B., Draper, M., \& Epperson, B. (2012). Aflatoxins hazards in grain/Aflatoxicosis and livestock. South Dakota State University (SDSU). Cooperative Extension Service / College of Agriculture \& Biological Sciences / USDA. Text adapted with permission from University of Maryland Cooperative Extension Service Fact Sheet [444 \& 445], FS 907: PDF by CES. October 2001, http://igrow.org/up/resources/ 02-2033-2012.pdf, accessed 08 oct. 2012. 
[13] Gonçalez, E., Pinto, M. M., Manginelli, S., \& Felicio, J. D. (2004). Dairy cows poisoned with cottonseed meal naturally contaminated with aflatoxins. Ciência Rural, 34(1), $171-4$.

[14] Maia, P. P., Bastos, M. E. P., \& de Siqueira, . (2007). Aflatoxins in pet foods- A Review. Revista da FZVA, 14(1), 235-257.

[15] Akande, K., Abubakar, M., Adegbola, T., \& Bogoro, S. (2006). Nutritional and health implications of mycotoxins in animal feeds: A review. Pakistan Journal of Nutrition, 5(5), 398-403.

[16] Arias, S. L., Mary, V. S., Theumer, M. G., \& Rubinstein, H. R. (2011). Micotoxicosis en animales de laboratorio. In: Ramos Girona AJ (ed.). Micotoxinas y micotoxicosis, Madrid, AMV Ediciones, 299-328.

[17] Bryden, W. L. (2012). Mycotoxin contamination of the feed supply chain: Implications for animal productivity and feed security. Animal Feed Science and Technology, 173(1-2), 134-58.

[18] Khlangwiset, P., Shephard, G. S., \& Wu, F. (2011). Aflatoxins and growth impairment: A review. Critical Reviews in Toxicology, 41(9), 740-55.

[19] Wu, F., Narrod, C., Tiongco, M., \& Liu, Y. (2011). The health economics of aflatoxin: global burden of disease. Working Paper 4, February Available from, http:// www.ifpri.org/sites/default/files/publications/aflacontrol_wp04.pdf, accessed 04 May 2012.

[20] Cortés, G., Carvajal, M., Méndez-Ramírez, I., Ávila-González, E., Galván, C., CastilloUrueta, P., et al. (2010). Identification and quantification of aflatoxins and aflatoxicol from poultry feed and their recovery in poultry litter. Poultry Science, 89, 993-1001.

[21] Bünzen, S., \& Haese, D. (2006). Controle de micotoxinas na alimentação de aves e suínos. Revista Eletrônica Nutritime, 3(1), 299-304.

[22] Mallmann, C. A., Tyska, D., Mallmann, A. O., Mallmann, B. A., \& Dilkin, P. (2008). Interação das micotoxinas e seus efeitos nos suínos. In: Simpósio Brasil Sul de Suinocultura (1.: Chapecó, SC). Anais do I Simpósio Brasil Sul de Suinocultura, Concórdia: Embrapa Suínos e Aves, 82-85.

[23] Oliveira, G., Ribeiro, J., Fraga, M., Cavaglieri, L., Direito, G., Keller, K., et al. (2006). Mycobiota in poultry feeds and natural occurrence of aflatoxins, fumonisins and zearalenone in the Rio de Janeiro State, Brazil. Mycopathologia, 162(5), 355-62.

[24] Alam, S., Shah, H., Khan, H., \& Magan, N. (2012). The Effect of Substrate, Season, and Agroecological Zone on Mycoflora and Aflatoxin Contamination of Poultry Feed from Khyber Pakhtunkhwa, Pakistan. Mycopathologia, 174(4), 341-9.

[25] Andretta, I., Kipper, M., Lehnen, C. R., \& Lovatto, P. A. (2012). Meta-analysis of the relationship of mycotoxins with biochemical and hematological parameters in broilers. Poultry Science, 91(2), 376-82. 
[26] Bianco, G., Russo, R., Marzocco, S., Velotto, S., Autore, G., \& Severino, L. (2012). Modulation of macrophage activity by aflatoxins $\mathrm{B}_{1}$ and $\mathrm{B}_{2}$ and their metabolites aflatoxins $\mathrm{M}_{1}$ and $\mathrm{M}_{2}$. Toxicon, 59(6), 644-50.

[27] FAO and IFIF. (2010). Good practices of the feed industry implementing the Codex Alimentarius Code of Practice in Good Animal Feeding. FAO Animal production and Health Manual n.9. Rome. Section 1. Health Hazards associated with animal feed.

[28] Biswas, A. K., Kondaiah, N., Anjaneyulu, A. S. R., \& Mandal, P. K. (2010). Food Safety Concerns of Pesticides, Veterinary Drug Residues and Mycotoxins in Meat and Meat Products. Asian Journal of Animal Sciences, 4, 46-55.

[29] Wyatt, R. D., Briggs, D. M., \& Hamilton, P. B. (1973). The Effect of Dietary Aflatoxin on Mature Broiler Breeder Males. Poultry Science, 52(3), 1119-23.

[30] Hamilton, P. B., \& Gralich, J. D. (1971). Aflatoxin as possible cause of fatty liver syndrome in laying hens. Poultry Science, 50, 800-4.

[31] Huff, W. E., Wyatt, R. D., \& Hamilton, P. B. (1975). Effects of dietary aflatoxin on certain egg yolk parameters. Poultry Science, 54, 2014-8.

[32] Zaghini, A., Martelli, G., Roncada, P., Simioli, M., \& Rizzi, L. (2005). Mannanoligosaccharides and aflatoxin $B_{1}$ in feed for laying hens: effects on egg quality, aflatoxins $B_{1}$ and $\mathrm{M}_{1}$ residues in eggs, and aflatoxin $\mathrm{B}_{1}$ levels in liver. Poultry Science, 84(6), 825-32.

[33] Azzam, A. H., \& Gabal, M. A. (1998). Aflatoxin and immunity in layer hens. Avian Pathology, 27, 570-7.

[34] Jand, S. K., Kaur, P., \& Sharma, N. S. (2005). Mycoses and mycotoxicosis in poultry: A review. Indian Journal of Animal Science, 75, 465-76.

[35] Jansen Van Rensburg, C., Van Rensburg, C. E. J., Van Ryssen, J. B. J., Casey, N. H., \& Rottinghaus, G. E. (2006). In vitro and in vivo assessment of humic acid as an aflatoxin binder in broiler chickens. Poultry Science, 85, 1576-83.

[36] Tessari, E. N., Oliveira, C. A., Cardoso, A. L., Ledoux, D. R., \& Rottinghaus, G. E. (2006). Effects of aflatoxin $B_{1}$ and fumonisin $B_{1}$ on body weight, antibody titres and histology of broiler chicks. British Poultry Science, 47, 357-64.

[37] Glahn, R. P., Van Campen, D., \& Dousa, T. P. (1994). Aflatoxin B ${ }_{1}$ reduces Na(+)-P(i) co-transport in proximal renal epithelium: Studies in opossum kidney (OK) cells. Toxicology, 92, 91-100.

[38] Martinez-de-Anda, A., Valdivia, A. G., Jaramillo-Juarez, F., Reys, J. L., Ortiz, R., Quezada, T., et al. (2010). Effects of aflatoxin chronic intoxication in renal function of laying hens. Poultry Science, 89, 1622-8.

[39] Applegate, T. J., Schatzmayer, G., Pricket, K., Trache, C., \& Jiang, Z. (2009). Effect of aflatoxin culture on intestinal function and nutrient loss in laying hens. Poultry Science, 88, 1235-41. 
[40] Jacobson, W. C., \& Wiseman, H. G. (1974). The transmission of aflatoxin $B_{1}$ into eggs. Poultry Science, 53, 1743-5.

[41] Bailly, J. D., \& Guerre, P. (2009). Mycotoxins in meat and processed meat products. In: Toldrá F (ed.). Safety of Meat and Processed Meat, Food Microbiology and Food Safety, New York, Springer, 83-124, Available from, http://www.springerlink.com/content/ m0562t7598299h5j/, accessed 16 April 2012.

[42] Hassan, Z. U., Khan, M. Z., Khan, A., Javed, I., \& Hussain, Z. (2012). Effects of individual and combined administration of ochratoxin $A$ and aflatoxin $B_{1}$ in tissues and eggs of White Leghorn breeder hens. Journal of the Science of Food and Agriculture, 92, 1540-4.

[43] Hussain, Z., Khan, M. Z., Khan, A., Javed, I., Saleemi, M. K., Mahmood, S., \& Asi, M. R. (2010). Residues of aflatoxin $B_{1}$ in broiler meat: Effect of age and dietary aflatoxin $\mathrm{B}_{1}$ levels. Food and Chemical Toxicology, 48(12), 3304-7.

[44] Kalpana, S., Aggarwal, M., Srinivasa Rao, G., \& Malik, J. K. (2012). Effects of aflatoxin $\mathrm{B}_{1}$ on tissue residues of enrofloxacin and its metabolite ciprofloxacin in broiler chickens. Environmental Toxicology and Pharmacology, 33, 121-6.

[45] Rodriguez-Amaya, D. B., \& Sabino, M. (2002). Mycotoxin research in Brazil: the last decade in review. Brazilian Journal of Microbiology, 33, 1-11.

[46] Trucksess, M. W., Stoloff, L., \& Young, K. (1983). Aflatoxicol and aflatoxins $B_{1}$ and $M_{1}$ in egg and tissues of laying hens consuming aflatoxin-contaminated feed. Poultry Science, 62, 2176-82.

[47] Resolution RDC № 7. (2011). Technical Regulation on maximum tolerated levels for mycotoxins in food. from February 18, http://www.brasilsus.com.br/legislacoes/anvisa/107378-7.html , accessed 28 June 2012.

[48] EUR LEX. (2012). http://eur-lex.europa.eu/pt/index.htm, accessed 25 June 2012.

[49] Thieu, N. Q., \& Pettersson, H. (2008). In vitro evaluation of the capacity of zeolite and bentonite to adsorb aflatoxin $\mathrm{B}_{1}$ in simulated gastrointestinal fluids. Mycotoxin Research, 24, 124-9.

[50] Batina, P. N., Lopes, S. A., Santurio, J. M., de Souza, C., \& Martins, D. B. (2005). The effects of the addition of sodic montmorilonite on the feeding diet on the biochemical profile of broiler chicken intoxicated by aflatoxin. Ciência Rural, 35(4), 826-31.

[51] Diaz, D. E., Hagler, W. M., Jr Hopkins, B. A., \& Whitlow, L. W. (2003). Aflatoxin Binders I: In vitro binding assay for aflatoxin $B_{1}$ by several potential sequestering agents. Mycopathologia, 156(3), 223-6.

[52] Magnoli, C. E., Astoreca, A. L., da Rocha Rosa, C. A., \& Dalcero, A. M. (2011). Micotoxicosis en aves. Ramos Girona AJ (ed.). Micotoxinas y micotoxicosis, Madrid, AMV Ediciones, 221-239. 
[53] Aravind, K. L., Patil, V. S., Devegowda, G., Umakantha, B., \& Ganpule, S. P. (2003). Efficacy of esterified glucomannan to counteract mycotoxicosis in naturally contaminated feed on performance and serum biochemical and hematological parameters in broilers. Poultry Science, 82(4), 571-6.

[54] Muhammad, D., Chand, N., Khan, S., Sultan, A., Mushtaq, M., \& Rafiullah, . (2012). Hepatoprotective role of milk thistle (Silybum marianum) in meat type chicken fed aflatoxin $\mathrm{B}_{1}$ contaminated feed. Pakistan Veterinary Journal, 32(3), 443-6.

[55] Rangsaz, N., \& Ahangaran, M. G. (2011). Evaluation of turmeric extract on performance indices impressed by induced aflatoxicosis in broiler chickens. Toxicology and Industrial Health, 27(10), 956-60.

[56] Salgado-Tránsito, L., Arjona-Román, J. L., Moreno-Martínez, E., \& Méndez-Albores, A. (2011). Effect of citric acid supplemented diets on aflatoxin degradation, growth performance and serum parameters in broiler chickens. Archivos de Medicina Veterinaria, 43(3), 215-22.

[57] Ciegler, A., Lillehoj, E. B., Peterson, R. E., \& Hall, H. L. (1966). Microbial detoxification of mycotoxins. Applied Microbiology, 14, 934-9.

[58] Tejada-Castañeda, Z. I., Avila-Gonzalez, E., Casaubon-Huguenin, M. T., CervantesOlivares, R. A., Vásquez-Peláez, C., Hernández-Baumgarten, E. M., et al. (2008). Biodetoxification of aflatoxin-contaminated chick feed. Poultry Science, 87(8), 1569-76.

[59] Doyle, M. P., \& Marth, E. H. (1978). Degradation of aflatoxin by lactoperoxidase. Zeitschrift für Lebensmitteluntersuchung und Forschung A, 166(5), 271-3.

[60] Basalan, M., Gungor, T., Aydogan, I., Hismiogullari, S. E., Erat, S., \& Erdem, E. (2006). Effects of Feeding Mycotoxin Binder (HSCAS) on Gastrointestinal Environment and Metabolism in Broilers at Later Ages. Archiva Zootechnica, 9, 5-9.

[61] Girish, C. K., \& Devegowda, G. (2004, 8-10 September). Efficacy of modified glucomannan (Mycosorb) and HSCAS to alleviate the individual and combined toxicity of aflatoxin and T-2 toxin in broiler chickens. Istanbul, Tukey. XXII'nd World Poultry Congress.

[62] EFSA, European Food Safety Authority (2009). Review of mycotoxin-detoxifying agents used as feed additives: mode of action, efficacy and feed/food safety: Scientific report submitted to EFSA by AFSSA, CODA-CERVA, INRA Clermont-Ferrand, INRA Toulouse, IRTA, ISPA; 192p. Grant number: CFP/EFSA/FEEDAP/2009/01. Available from http://www.efsa.europa.eu/en/scdocs/doc/22e.pdf 
